\title{
Clarifying a Circularity Phenomenon in a Circular Economy under the Notion of Potential
}

\author{
Wyjaśnienie zjawiska kołowości w gospodarce \\ o obiegu zamkniętym w kontekście pojęcia potencjału
}

\section{Tetiana Shevchenko*, Roman Vavrek**, Yuriy Danko*, Olena Gubanova ${ }^{\star \star \star}$, Jana Chovancová ${ }^{\star \star \star \star}$, Liubov Mykhailova ${ }^{\star}$}

\author{
*Sumy National Agrarian University; H. Kondratiiev 160, 40021 Sumy, Ukraine \\ E-mails:tanya_goncharova@meta.ua,yuriy.i.danko@gmail.com,lmikhaylova@yahoo.com \\ **VŠB-Technical University of Ostrava; Sokolská třida 33, 70200 Ostrava, Czechia; \\ E-mail (Corresponding Author): vavrek.roman@gmail.com, ORCID: 0000-0002-6047-9434 \\ ***Odessa State Environmental University; Lvivska 15, 65016 Odessa, Ukraine. \\ E-mail: askoldov@ukr.net \\ ****University of Prešov; Konštantínova 16, 08001 Prešov, Slovak Republic; \\ E-mail: jana.chovancova@unipo.sk
}

\begin{abstract}
Turning from linear to circular business model, from cradle-to-grave to cradle-to-cradle and from waste to wealth, the concept of circular economy (CE) has become an important tool to promote sustainable development as it combines economic, environmental and social benefits at a local as well as global scale. In the shift towards CE, examining the $\mathrm{CE}$ from the perspective of its potential is crucial for its wider and more effective implementation in the practice. The aim of the paper is to clarify a circularity phenomenon in closed-loop economy under the notion of potential in part of (1) the structural elements, (2) underlying categories and (3) basal properties as a follow-up to the previous studies about managing the circularity potential. The study provides the theoretical framework for understanding circularity potential by developing the circularity potential categorization in order to get a comprehensive picture of what has been done in the past and where efforts are most need today to achieve a progress towards circularity in the future. The basal properties of circularity potential such as integrity, dynamism, territorial affiliation and different strategies compatibility were revealed and discussed for managing the circularity potential. The findings of the paper have ambition to contribute to new metrics development to measure the progress towards zero-waste and CE aimed at identification and monitoring all the possible forms of the circularity potential - opportunities, reserves, available resources, rather than the available resources only that were primarily considered in the past attempts at the operationalisation of circular economy.
\end{abstract}

Key words: circular economy, circularity potential, zero waste, reuse potential, recycling

\section{Streszczenie}

Przechodząc od modelu biznesowego liniowego do cyrkularnego, od kotyski do grobu do od kotyski do kotyski i od odpadów do bogactwa, koncepcja gospodarki o obiegu zamkniętym (CE) stała się ważnym narzędziem promowania zrównoważonego rozwoju, ponieważ łączy w sobie ekonomię, korzyści środowiskowe i społeczne w skali lokalnej i globalnej. W przejściu na CE, zbadanie CE z perspektywy jej potencjału jest kluczowe dla jej szerszego i efektywniejszego wdrożenia w praktyce. Celem artykułu jest wyjaśnienie zjawiska kołowości w gospodarce o obiegu zamkniętym w kontekście pojęcia potencjału w części (1) elementów strukturalnych, (2) podstawowych kategorii i (3) podstawowych właściwości, co stanowi kontynuację poprzednich badań dotyczących zarządzania potencjałem obiegu zamkniętego. Badanie ukazuje ramy teoretyczne potencjału obiegu zamkniętego poprzez opracowanie kategoryzacji potencjału obiegu zamkniętego w celu uzyskania kompleksowego obrazu 
tego, co zostało zrobione w przeszłości i czego należy dokonać teraz, aby osiągnąć postęp w kierunku obiegu zamkniętego w przyszłości. Podstawowe właściwości potencjału obiegu zamkniętego, takie jak integralność, dynamizm, przynależność terytorialna i zgodność różnych strategii, zostały omówione w celu zarządzania potencjałem obiegu zamkniętego. Wnioski zawarte w artykule prowadzą w kierunku opracowania nowych mierników do pomiaru postępu w kierunku zero-waste i CE, których celem jest identyfikacja i monitorowanie wszystkich możliwych form potencjału obiegu zamkniętego, a więc: możliwości, rezerwy, dostępne zasoby, a nie jedynie dostępne zasoby, które były brane pod uwagę przede wszystkim w poprzednich próbach operacjonalizacji gospodarki o obiegu zamkniętym.

Słowa kluczowe: gospodarka o obiegu zamkniętym, potencjał obiegu zamkniętego, potencjał ponownego wykorzystania, zero waste, recykling

\section{Introduction}

Since the Stockholm Conference in 1972, a series of Environmental Action Programmes have been launched at the level of the European Community. So far, seven such programmes have been established supporting the sustainable development strategy of the European Union. The Seventh Environmental Action Programme is the new general Union Environment Action Programme to 2020, Living well, within the limits of our planet, was approved in 2013 (Decision, 2013), where a new broader meaning appeared in the formulation of tasks concerning the management of resources and waste - to move towards a lifecycle-driven 'circular' economy, with a cascading use of resources and residual waste that is close to zero. The concept of CE was supported also by other policy documents such as EU Action Plan for the Circular Economy (EC, 2015), An European strategy for Plastics in a Circular Economy (EC, 2018).

The CE paradigm is being widely explored by researchers as well as practitioners as a possible path to increase the sustainability of current economic system (Skene, 2017; Elia et al., 2016). Today, there are a lot of comprehensive studies to holistically define and conceptualize the $\mathrm{CE}$. The recent impulse for operationalisation has been catalyzed by the first CE standard BS 8001:2017 proposed by British Standards Institution (BSI, 2017) where the CE is interpreted as economy that is restorative and regenerative by design, and which aims to keep products, components and materials at their highest utility and value at all times, distinguishing between technical and biological cycles. Further, restorative implies spent resources being fed back into new products and regenerative - the enabling of living systems to heal and renew the resources that are consumed (BSI, 2017). It is fair to say that the Ellen MacArthur Foundation (EMF) has played a pivotal role and served as a solid theoretical platform for CE conceptualization and operationalisation. Especially, EMF's butterfly figure has been successful tool to visualize a circularity strategies hierarchy by the priority reuse-repair-refurbishment-remanufacturing-repurposerecycling (EMF, 2013a; Bocken et al., 2017).

Following to the EMF's butterfly figure, $\mathrm{CE}$ is intended to be purposively restorative through two types of flow: (1) nutrients re-entering the biosphere and (2) synthetic materials intended to be used repeated with limited loss in value (EMF, 2013a). The synthetic or mineral material that has the potential to remain safely in a closed-loop system of manufacture, recovery, and reuse, maintaining its highest value through many product life cycles, can be defined as a technical nutrient, according to some thoughts (Braungart et al., 2007; Bocken et al., 2016). In the meantime, whether the undesirable output will become a technical nutrient or not, it depends on a lot of circumstances (Kronenberg and Winkler, 2009). Owing to the change in technologies development (Park and Chertow, 2014) and economic circumstances, the mentioned above potential is continuously changing over space and time.

In order to continuous building-up the circularity potential according to the priority in circular strategies, there is a need to develop a theoretical framework of managing the circularity potential. In the previous study (Shevchenko and Kronenberg, 2020), we proposed an approach to operationalise the circular economy based on the management of circularity potential by the phases: optimal allocation of available potential, maximum use of allocated potential, and new potential building-up. In this study, we continue to develop this approach in the part of examining underlying categories of the circularity potential term. The purpose of this study is to provide the theoretical framework for deeper understanding the circularity potential by developing circularity potential categorization in order to clarify what has been done in the past and where efforts need to be made today for growth product and material's circularity in the future. Furthermore, in this paper we will examine the basic properties of circularity potential such as integrity, dynamism, territorial affiliation and compatibility of different strategies. The outcomes of the study can create the theoretical basis for the development of new metrics for measuring progress towards zerowaste and circular economy aimed at identifying and monitoring all the possible forms of the circularity potential - opportunities, reserves, available resources, rather than the available resources only which were primarily considered in the past attempts at the operationalisation of circular economy. 
The article is structured as follows: The Theoretical background section elucidates the circularity phenomena through the prism of possible value creation sources from undesirable outputs in economic system. In addition, exploring of the phenomenon of circularity potential is actualized by examining the space and time content as well as by existence of contradiction in circular strategies. The Results section provides the theoretical framework for deeper understanding the category circularity potential by developing the circularity potential categorization. The Discussion section expounds the findings discussed in the light of recent studies. In conclusions we summarise the main research results as well as outline possible paths for future research.

\section{Theoretical background}

\subsection{Circular economy concept in light of contribu- tion to sustainability}

The issue of sustainable development and a circular economy is discussed in the scientific community in the context of conceptual similarities and differences (Geissdoerfer et al., 2017), circularity as one archetype of sustainable business models (Bocken et al., 2014), economic activity and environmental wellbeing (Murray et al., 2015), a possible way to operationalize sustainable development (Potting and Kroeze, 2010), reasonable compromise for opposing strategies (Allwood et al., 2012; Prokopenko et al., 2014) and conditional relation (Rashid et al., 2013; Bocken et al., 2014). Based on the comprehensive literature review, Geissdoerfer and colleagues (2017) revealed that the circular economy is conceptually related to sustainability, namely circular economy is viewed as a condition for sustainability. At the same time, these researchers highlight that the actual impacts of Circular Economy initiatives need to be investigated - how do these perform against the triple bottom line (economic performance, social inclusiveness, and environmental resilience) and contribute to strong sustainability and slower forms of consumption? In this line of reasoning, although the debate about conceptualization of the circular economy is still being conducted in the scientific community (Blomsma and Brennan, 2017), the issue on the implementation of this model lies in the plane of policies and strategies that should ensure continuous building-up of the circularity potential and maximum use of available potential (Park and Chertow, 2014) based on priorities of 6Rs circular strategies to save the value as long as possible as well as in the line with sustainability by three pillars towards sustainable development goals.

\subsection{Value creation sources driven by circular busi- ness model}

The CE concept represents the most recent attempt to conceptualize the integration of economic activity and environmental wellbeing in a sustainable way
(Murray et al., 2015). In a narrow sense, it is one of several different concepts that has been useful in the quest to understand how materials and resources can be used most efficiently (Circular Academy, 2017; Petrushenko and Shevchenko, 2013). In terms of implementation, the current situation can be characterized as one where interpretations abound but theoretical or paradigmatic clarity regarding the $\mathrm{CE}$ concept has yet to emerge (Blomsma and Brennan, 2017). They argued that there is ample ground to conceptualize the $\mathrm{CE}$ as an umbrella concept; this becomes evident when comparing and contrasting various frameworks in which circularity plays an important role.

A worldwide trend is leading the international community to explore possible paths for the transition from linear to circular business models (Elia et al., 2016). According to the calculations, only in the EU, the saving of material resources could reach 380 billion dollars while implementing circular business models. Such conclusions were made by experts while assessing business potential of value creation from waste (EMF, 2013a). In 2017, the British Standards Institution launched the first CE standard BS 8001:2017 - Framework for implementing the principles of the CE in organizations' which is intended to help organizations and individuals consider and implement more circular and sustainable practices within their businesses, whether through improved ways of working, providing more circular products and services, or redesigning their entire business model and value proposition (BSI, 2017; Pauliuk, 2018). So far, organizations had no authoritative guidance on CE principles, strategies, implementation, and monitoring. It does not contain requirements that must be met, which means that it is not possible to claim compliance to the standard or undertake some form of certification (Pauliuk, 2018).

Today, four possible sources of value creation through circular business models have been identified by EMF specialists (EMF, 2013a). The first one - power of the inner circle - the tighter the circle is, the less frequent replacements (repair, upgrading or recycling) are needed for product; the faster product is returned to use, the higher the potential savings of material, labour, energy and capital are embedded in the product and the less damage from environmental pollution in the form of negative externalities effects, in particular greenhouse gases, emissions, discharges and waste. The second source - power of circling longer - provides for maximizing the number of cycles and each cycle's duration. The third source - power of cascading use - it consists in the diversification of the reuse of material in the value creation chain, for example, a cascading cotton chain clothes - furniture - building materials, then material is expected to be emitted safely into biosphere. The last one - power of pure circles - provides the improvement of the material productivity through 


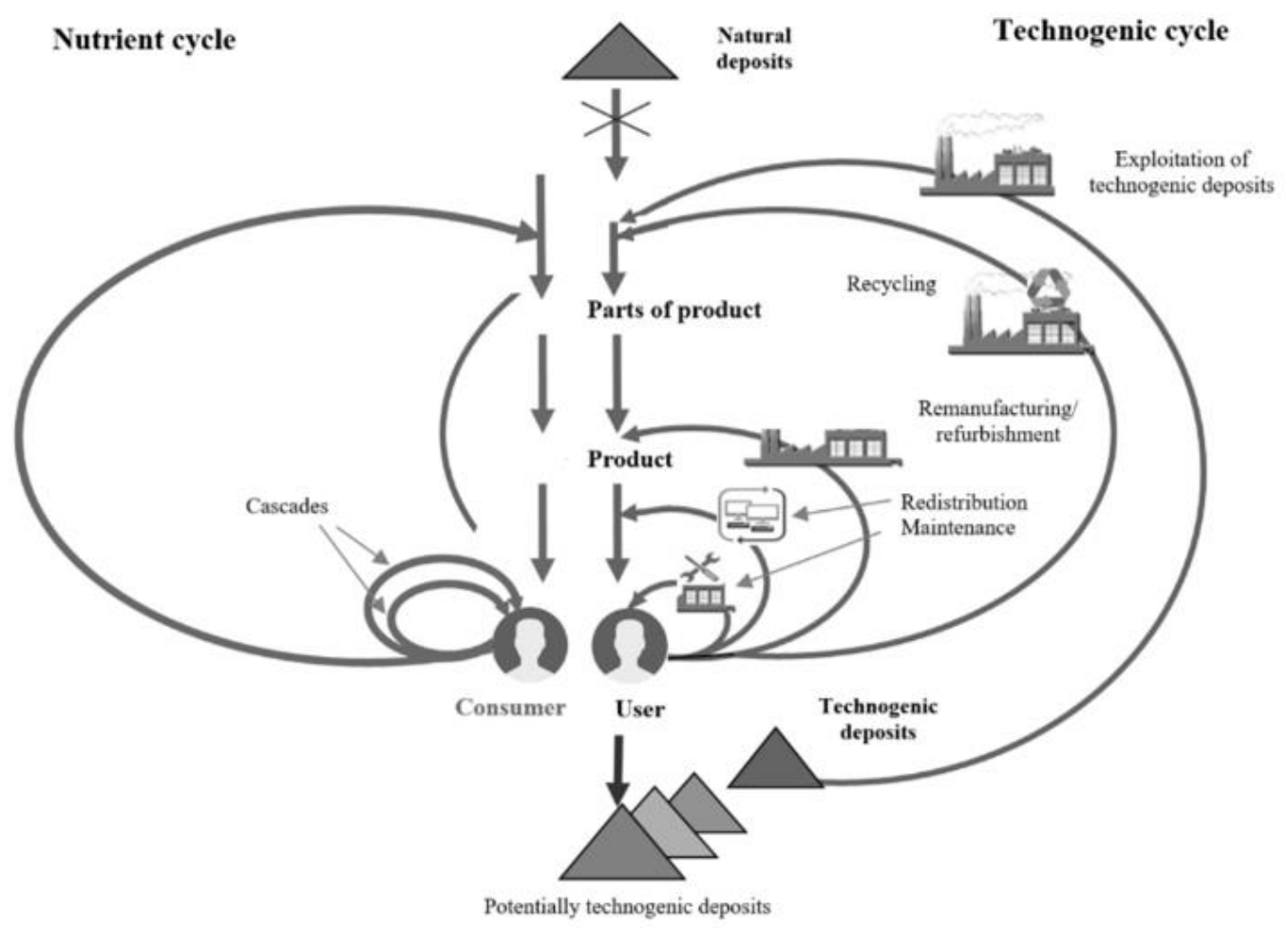

Figure 1. Modified conceptual scheme of a circular economy (EMF, 2013a)

the use of safe non-toxic materials, including bio-investment materials, in particular bioplastic and biopolyetylene. These sources essentially represent the circularity potential, which should be managed in terms of continuous building-up.

Den Hollander et al. (2017) recent study introduces a set of new concepts and definitions, including the leakage - a term for products or their components/materials that flow from the circular economic system to the biosphere, and that cannot be recovered at the present time (Den Hollander et al., 2017). From this perspective, one more value creation source could be added - the power of the technogenic deposits use that refers to restarting for the use of technogenic stocks which were returned to the biosphere in default of available technologies at the territory in the past. It could be one more source of value creation towards continuity of interrupted cycles. Technogenic deposits intrinsically should be considered as a source of materials to compensate for the material inherent losses in a CE instead of natural deposits. Taking into account additional source of value creation, the conceptual scheme of a $\mathrm{CE}$, suggested by experts of the EMF, will be as pictured below in Figure 1.

The lack of available recycling technologies for the undesirable outputs in economic system, as well as the prevailing stereotypes of the linear model, led to the creation of a large number of technogenic deposits in many countries around the world. Technogenic mineral deposits include attributed dumps, slurry pits, tailings ponds, landfills, slag heaps, rubbish dumps etc. Today, many technogenic deposits have higher content of valuable components than natural deposits. For example, in Ukraine the content of scandium, vanadium, tantalum, chromium, titanium in the waste of the Zaporozhye Titanium and Magnesium Combine are higher than in natural deposits. Many valuable components are contained in the waste of Mykolayiv Mercury Combine (lithium, mercury), Cherkassy State Plant of Chemical Reagents (nickel) etc. Scientific research and practical experience testify to the high resource potential of production wastes that were generated 20 years ago. Due to the imperfection of mining technologies, up to $70 \%$ of oil, $30 \%$ of coal, $20 \%$ of iron ore remained unmined, planned losses of hard coal were $40 \%$, and $50 \%$ for oil. During the extraction of potash salts and mica, $80 \%$ of raw materials remained in the dumps (Gubanova, 2009).

\subsection{Contradiction in circular strategies}

Franklin-Johnson et al. (2016) highlighted that circularity phenomenon does not have any value in itself, but it implies increasing the amount of time during which a resource provides value. That is captured in the longevity indicator and this measure addresses resource longevity and not product longevity according to this study (Franklin-Johnson et al., 2016). However, circular economy is all about the initiatives that can create an important impact on materials use, and case studies have shown that an increased serviceable life or higher usage intensity lead to substantial materials savings, for example, reusable bottles (EMF and Granta, 2015). Therefore, discussion about product circularity inevitably leads to discus- 
sion of circularity of materials that constitute these products (Bocken et al., 2017). The question arises regarding product circularity: is a product more circular due to it is used longer, even if it is landfilled after use? Regarding the importance of using the potential of slowing down the material loop as much as possible (Stahel, 2010), it's worth to note that the restoration of the product/modules/parts is aimed at short period of value preservation. Even with the technical possibility of restoration, in most cases, new products displace old ones from the market because the former become more attractive to the consumer and more efficient for the manufacturer, especially for electrical and electronic equipment refers to the up-to-date products category (Cox et al., 2013) according to the product topology based on product lifetime preferences. Thus, in the long term, the priority should be given to the preservation of value of material the product is made of (Braungart et al., 2007), and the issue of reuse of the product should be considered in the context of the possibility of extending in time the turn of each of these materials. In this context, the combination of circular strategies in order to maximize the longevity of the material using is quite important. By the opinion of Blomsma and Brennan (2017), the CE concept implies a shift away from implementing and assessing singular strategies, to the assessment of different circular configurations - situations where two or more different strategies work together in sequence or in parallel. To justify such configurations, quantitative parameters have to be supplemented with qualitative parameters in particular, recycling metric must be based on clear definitions of inputs and outputs, considering the time axis and material stocks along this time axis as well as the different qualities and constituents of materials must be taken into account (Velis, 2013).

\subsection{Understanding of circularity phenomenon in terms of the potential}

Various interpretations of potential with regard to the CE have been mentioned in the reports of the EMF (2013a; 2013b; 2014) which are indisputably broad and reflect a wide range of mechanisms and approaches to operationalise the CE. In particular, the phrase potential for the circular economy (EMF, 2013a; 2014) implies a circular design, innovative business models, core competencies along reverse cycles and cascades, enablers to enhance cross-cycle and cross-sector performance. This interpretation reveals the essence of appropriate potential as being unused opportunities and available resources. The term circularity potential and a similar interpretation - the full circularity potential (EMF, 2013b) connotes a set of opportunities in the context of analysing the supply chains of circular businesses as well as suggests that making the reverse circle as short as possible is essential to capturing the complete circularity potential. The full potential of going circular 'signifies all companies' readiness to perform activi- ties in accordance to the tasks of the CE (EMF, 2013a). Deserving attention study about a reuse potential was conducted by Park and Chertow (2014), where for the first time was made an attempt to describe properties of reuse potential for materials investigating the extent of technological development. These scientists argued that material's reuse potential is dynamic and not an inherent property of waste owing to its reliance on technological development. By the opinion of Park and Chertow (2014) the concept of reuse potential is inherently time dependent because of the reuse potential increases as technological options increase in length of time therefore enabling more material recovery, or vice versa devolutionary process. Furthermore, since reusability varies regionally owing to differences in material quality and the level of technological development, reuse potential also depends on the geographical boundaries. Lastly, reuse potential is influenced by the level of material generation inasmuch as larger quantity of material generation requires appropriate technological development.

\subsection{Rethink reuse potential: towards continuous building-up of circularity potential}

The CE is ultimately linked to resource cycling (Murray et al., 2015). The aspect of multiple material cycling is reflected in industrial symbiosis (Domenech et al., 2019), multiple product cycling in the service economy by means remanufacturing and maintenance (Piscicelli et al., 2015). We argue that to preserve the value of a material means to provide a distinct way for its multiple transformations in an economy which can be presented as a material cycle measured by (1) the number of turns and (2) the duration of each turn. The latter, i.e. the duration of the specific material's turn, is caused by the maintenance of the product value. These two parameters of the material's cycle could become the characteristics that require to be monitored, the characteristics that measure the material and product circularity.

We argue that a growth of the number of material's turns and the time of each turn is due to the buildingup, optimal allocation and as full as possible use $m a$ terial circularity potential and product circularity potential. In the previous studies (Shevchenko and Kronenberg, 2020), the material and product circularity potential proposed to understand as multilevel, integrated and dynamic complex of all kinds of explicit opportunities, unused/partially used reserves and available resources, including the prospects for their increase, which are used/can be used to ensure the material and product multiple turnover in the economic system. The approach to investigate the material and product circularity from the point of view of the potential is aimed at the identification of all possible forms of potential appearances of a given material or product in space and time. Therefore, opportunities, reserves, available resources, as forms of appearances of the potential, are its integrated set, as 
they are concentrated within single regenerative system.

The continuous building-up of material's circularity potential can be interpreted as a process of (1) identifying and creating opportunities or preconditions and necessary resources to provide the circularity of specific material within the system, (2) structuring and arranging opportunities and available resources across all participants' actions within a system, and finally, (3) identifying the implicit opportunities for growth of the potential in the future. In a broader sense, it implies that the circle-oriented processes should be stipulated, executed and intensified within the lifecycles of corresponding products as elements of the modelled material cycle. The optimal allocation of the material circularity potential implies a process of allocation of available potential by modelling the optimal range of products based on a minimum loss of the original value of the specific material. The material that is to be allocated makes the $\mathrm{j}^{\text {th }}$ turn and proceeds to the following $(\mathrm{j}+1)$ turn in accordance with the modelled distinct way of material flow. The fullest use of material circularity potential implies that the material of the specific turn should be involved in the production of the specific product in accordance to the modelled optimal range of product. Furthermore, the fullest utilisation of circularity potential is comprised by respecting the priorities of the three main cycles: product repair, product upgrading or modernisation and material recycling.

\section{Results}

\subsection{Categorization of circularity potential}

Before we proceed to examining the underlying categories of circularity potential, it is necessary to clarify its structural elements for which these categories will serve as a means for assessing current status. Relying on the fact that the material's circularity potential appears thought all stages of the material life cycle (mining, processing and use), including product life cycles (design, production, consumption and reuse) in part of the material cycling (Shevchenko and Kronenberg, 2017), hence the structural elements of the potential should be the following: (1) circular product design; (2) circular business models and procircular products manufacturing; (3) pro-circular consumer behaviours and (4) reuse and recycling technologies. Below are a few words about the essence of these components.

According to recent studies (Hollander et al., 2017; Bocken et al., 2016), circular product design encompasses both design for product integrity that aimed at preventing and reversing obsolescence at a product and component level as well as design for recycling - aimed at preventing and reversing obsolescence at a material level. Regarding circular business models, Bocken et al. (2014) argued that the creation of value from waste is one of the archetypes of sustainable business models, within it such forms of circular business models as (1) industrial symbiosis, (2) closed-loop business models, (3) cradle-to-cradle, (4) under-utilized assets and capabilities are highlighted (Bocken et al., 2014; Braungart et al., 2007). Concerning pro-circular consumer behaviours, it's worth noting that the significance of consumer for circular economy is difficult to overemphasize since this actor determines the demand for pro-circular products, namely for: the reusable and recyclable products (Kautish et al., 2019), refurbished and remanufactured products (Weelden et al., 2016), recycled products (Park and Lin, 2018), shared products (Piscicelli et al., 2018), upcycled products (Bridgens et al., 2018), repaired and used before products (Neto et al., 2016). In our opinion, in the context of a CE, consumer behaviour has a triangular essence, that is, behaviour could be considered as a structural unity formed by three separate elements, namely product customer, product user and end-of-life product holder. Basically consumer builds-up the circularity potential by proper purchasing and care using as well as contributes to the fullest use of this potential by proper discarding from EoL products.

Reuse and recycling technologies (Jawahir and Bradley, 2016) and innovations (Pieroni et al., 2019; Mont et al., 2017) are a crucial structural element of the circularity potential as it is the driving force in building-up the materials and products' frequency of using and longevity of turnover. 6R-based technological elements are identified as essential components for achieving economic growth, environmental and societal benefits in the recent state-of-the-art study by Jawahir and Bradley (2016). The typology of recycling technologies proposed by Gladyshev (2013) consists of the following types of technologies: the basic recycling technologies, the satellite recycling technologies, the autonomous technologies, the hybrid technologies, the assimilation technologies. By analogy with recycling technologies, the reuse ones can be intended for repair, refurbishment, remanufacturing of product. In order to assess the aforementioned structural elements of the circularity potential, the following underlying categories have been identified and classified by the features: (1) the form of appearance, (2) the time feature, (3) the availability, (4) the degree of appearance, (5) the degree of formation of explicit potential, (6) the degree of use of available potential, (7) the level of concentration, (8) the type of appearance (Tab. 1).

To develop national CE action plan towards building-up the circularity potential, such its basal properties as integrity, dynamism, territorial affiliation and compatibility of different strategies should be taken into account. Integrity of circularity potential implies dependence of each element of the potential, i.e. the impact on one or more elements of the system necessarily causes a reaction, a change in other elements. Dynamism of circularity potential is its property that stipulated by technological development, 
Tab. 1. Categorization of circularity potential

\begin{tabular}{|c|c|}
\hline Categorization feature & Underlying categories \\
\hline 1. Form of appearance & $\begin{array}{l}\text { - available resources } \\
\text { - unused or partially used reserves } \\
\text { - explicit and implicit opportunities }\end{array}$ \\
\hline 2. Time feature & $\begin{array}{l}\text { - in terms of the past (factual) } \\
- \text { in terms of the present (technically possible) } \\
\text { - in terms of the future (perspective) }\end{array}$ \\
\hline 3. Availability & $\begin{array}{l}\text { - available } \\
\text { - unavailable }\end{array}$ \\
\hline 4. Degree of appearance & $\begin{array}{l}\text { - explicit } \\
\text { - implicit } \\
\end{array}$ \\
\hline 5. Degree of formation of explicit potential & $\begin{array}{l}\text { - formed } \\
\text { - partially formed } \\
\text { - unformed }\end{array}$ \\
\hline 6. Degree of use of available potential & $\begin{array}{l}\text { - used } \\
\text { - partially used }\end{array}$ \\
\hline 7. Level of concentration & $\begin{array}{l}- \text { at the national level } \\
\text { - at the level of the region/city } \\
\text { - at the level of the territorial-branch cluster } \\
\text { - at the entity level }\end{array}$ \\
\hline 8. Type of appearance & $\begin{array}{l}\text { - internal in relation to the studied territory } \\
\text { - external }\end{array}$ \\
\hline
\end{tabular}

economic circumstances and geographical movement of materials and products. Park and Chertow (2014) highlighted that reuse potential has reliance on technological development, is dynamic and has not an inherent property of waste - the reuse potential increases as technological options increase, enabling more material recovery. The authors indicated that the concept of reuse potential is inherently time dependent, it can track how materials change from waste into a potential resource or vice versa, representing an evolutionary process or even a devolutionary one (Park and Chertow, 2014). Furthermore, the circularity potential changes due to geographical movement of materials and products (Komar, 1975) as well as economic circumstances that change over time (Kronenberg and Winkler, 2009). Hence, inherently circularity potential for specific materials and products is an acquired property both of them that has a dynamic character. The territorial affiliation is one more property of circularity potential. Park and Chertow (2014) argued that defining temporal and geographical scope is important for calculating a reuse potential; reusability varies regionally due to differences in material quality and the level of technological development, therefore it depends on geographical boundaries. Compatibility of different strategies as a property of circularity potential implies finding ways to integrated material's and product's strategies. These ways provide the different circular configurations - situations where two or more different strategies work together in sequence or in parallel according to Blomsma and Brennan (2017). Configurations of circular strategies should be based on the fact that reuse potential of final product is limited due to the limited useful life of product and its parts, and reasoning from the long term, recycling potential is a crucial purpose for circular economy operationalisation.

\subsection{Pro-circular consumer behaviours}

The social dimension of sustainability in terms of social wellbeing has a weak reflection in studies on the circular economy compared to economic performance and environmental resilience and mainly present in view of job creation (Geissdoerfer et al., 2017; Webster, 2015). We believe that among a number of economic models that recently have been widely discussing in the scientific community, such as the green economy, blue economy, and circular economy as contributing to sustainability, the latter has a fairly clear social dimension. In a wide sense, for the circular business model, social wellbeing occurs within more circular consumption alternatives built on capitalizing on residual value of materials and products. Collaborative consumption (Piscicelli et al., 2018) and pro-circular product purchasing are two alternative models towards circular flows of products and materials and thereby contributing to more sustainable consumption. Careful using of product, its repairing and maintenance lead to longer product life spans securing progress toward more circular using alternatives contributing to slowing the loop. The proper EoL product discarding is a crucial action of consumer activity among other ones because of creation the preconditions for reuse and recycling in the future. In terms of sustainability procircular purchasing, careful using and proper EoL product discarding contribute to reducing the pressure on virgin natural resources by extending the use time of products, their parts and materials, decreasing the amount of energy use and pollution from the production of new products, and cutting production 
and post-consumer volumes of waste (Mont and Heiskanen, 2015). Therefore, the circular economy model allows us to increase the social wellbeing for the current generation without increasing the consumption of primary resources, thereby leaving the possibility for future generations to ensure their wellbeing.

Bellow we explain how to apply the new circularity potential dimension to specific examples of material applications to clarify that in some cases the new dimension is extra relevant.

\subsection{Application of the new 'circularity potential' di- mension}

A few brief examples are provided bellow for two different material applications to clarify the new circularity potential dimension:

(1) stainless steel in a car,

(2) lithium in a battery.

Conversely, the new dimension application to stainless steel in a car is an essential because of huge potential of subsequent use of this material as reinforcement iron and frames for buildings. Today, circularity potential of stainless steel used in cars can be identified in forms of available resources, unused reserves and explicit opportunities. In the context of reuse and recycling technologies as a structural element of the potential, the available resources parameter is reflected in the available recycling technologies that already have covered specific volume of old cars' stainless steel for using as reinforcement iron and frames for buildings. In a case that technologies are available but stainless steel is not covered by them, circularity potential has the form of unused reserves (technically possible potential). And the last form - explicit opportunities reflect the need to develop appropriate recycling technologies in volume to recycle uncovered stainless steel of old cars at the territory.

In the case of application of lithium in a batteries, the new potential circularity dimension is crucial because of the available potential of recycling technologies to subsequent use of lithium is virtually not existing today. Today, production technology of the lithium-ion batteries is still evolving, making their recycling more difficult, a large number of manufacturers and various product applications have jumped into the direct lithium-ion battery industry or indirect consumer electronics and electric vehicles, which have aggravated the recycling issue (Zeng et al., 2014). Consequently, for lithium used in batteries, the circularity potential in terms of reuse and recycling technologies can be identified in the form of implicit opportunities to a greater extent. Buildingup of lithium' circularity potential is essential to enable the gradual transformation of opportunities into available resources.

In addition to reuse and recycling technologies, for measurement of circularity for stainless steel used in a car and lithium used in a battery, it is also important to consider other structural elements of the potential. For instance, circular product design simplifies batteries removal, if it is mounted in the device, as well as sorting and identification processes. Pro-circular consumer behavior contributes to proper batteries return through collection systems. Regarding lithiumion batteries separate collection, the availability of sufficient and convenient infrastructure and carrying out awareness raising companies that provide specific batteries collection rate indicates the available circularity potential in the form of available resources, in turn, the absence of any infrastructure can be considered as a potential in the form of explicit opportunities that can be realized in the future.

To track a progress towards the operationalisation of a circular economy, it is essential to record all the efforts made related to circular product design and circular business models development, changes in consumer's behavior, development of new production and recycling technologies. Assessing the circularity potential by all its structural elements through proposed underlying categories allows to get a comprehensive picture of what has been done in the past and where efforts are most needed today to achieve a progress in the future.

\section{Discussion}

In the previous study (Shevchenko and Kronenberg, 2020), we developed an approach for a circular economy operationalisation based on the management of circularity potential by the phases: optimal allocation of available potential, maximum use of allocated potential, and continuous building-up of new potential. This approach could become a theoretical and methodological basis to develop the appropriate policies and strategies. Currently practical implication of circular economy ideas implies minimizing undesirable outputs inside the system that generates these outputs (Park and Chertow, 2014; Domenech et al., 2019). In order to make the action plan more specific, the circular economy concept should include an obligation to use a recycled resource for manufacturers of certain product categories. Namely allocation of available circularity potential, as a phase of management of circularity potential, allows to provide not only the restriction of an access of manufacturers of certain products to use the primary resource but to establish the only one possible access to the recycled material of a particular turnover, thereby creating demand for these or other outputs and allowing the maximum number of turns of the specific material.

We start with exploring sources of capitalizing on residual value of materials and products and propose to consider technogenic deposits as an additional potential source of value creation to compensate for the inherent losses of materials in the circular economy. It seems logical that for a circular model, the involvement of a primary resource is necessary due to 
compensation for the inherent losses of materials as well as to meet growing needs if growth takes place. We argue that in order to compensate the inherent losses of materials in the circular economy, technogenic deposits should be considered as a source of materials rather than natural deposits. Relying on the Den Hollander and colleagues' study about leakage, it could be one more source of value creation - the power of the technogenic deposits use, which refers to restarting the use, after an interruption cycle, the technogenic stocks that were returned to the biosphere in default of available technologies in the past. Due to the linear economic model, currently there is a tendency of the gap between the development of production technologies and recycling technologies. The gap consists in the fact that recycling technologies are being developed for wastes that were generated in the past, and with the development of production technologies, the characteristics of wastes change, and, as a result, the search for recycling technologies for these wastes becomes the problem of future generation. Therefore, the conclusion is that the technological opportunities for recycling will always be limited because of recycling technologies are not developed simultaneously with production technologies. This discrepancy can be eliminated by providing technical decomposer for coverage all undesirable outputs of a new process created by production technology. However, even with the principal availability of recycling technology, the accumulation of waste may occur due to the fact that economic circumstances have changed over time, that is, they have become less favourable. Hence, the creation of technogenic deposits is a fatal process, due to the continuous change in economic circumstances and/or the development of production technologies. With the depletion of natural deposits, the development of recycling technologies and changes in economic circumstances, many technogenic reservoirs should be considered as potential full-fledged mineral deposits of technogenic type. In view of the additional source, the conceptual scheme of circular economy, EMF's butterfly figure, has been modified based on the extended list of possible sources of value creation through the circular business models.

Unlike previous studies (Geissdoerfer et al., 2017; EMF, 2013a; 2013b; 2014; Park and Chertow, 2014), the circularity potential categorization as a mean to assess the current situation and the circularity potential as a new dimension allows to get a comprehensive picture of what has been done in CE operationalisation in the past and where efforts are most needed today to achieve a progress in the future. To clarify the new circularity potential dimension, a few brief examples are provided for two different material applications. Furthermore, we argue that in order to build-up the circularity potential, such basal properties of circularity potential as integ- rity, dynamism, territorial affiliation, and compatibility of different strategies should be taken into account when developing national and regional $\mathrm{CE}$ action plans. The findings contribute to new metrics development to measure the progress towards zerowaste and $\mathrm{CE}$ aimed at identification and monitoring all the possible forms of the circularity potential opportunities, reserves, available resources, rather than the available resources only that were primarily considered in the past attempts at the operationalisation of circular economy (Franklin-Johnson et al., 2016; EMF and Granta, 2015).

\section{Conclusions}

This article attempts to clarify a circularity phenomenon in closed-loop economy under the notion of potential in part of the structural elements, underlying categories and basal properties as a follow-up to our previous studies about managing the circularity potential. Relying on the fact that the material circularity potential appears thought all stages of the material life cycle, the structural elements of circularity potential should be the following: circular product design, circular business models and pro-circular products manufacturing, pro-circular consumer behaviours, reuse and recycling technologies. To scan current status by marked circularity potential structural elements, the set of underlying categories have been identified and classified by different features, in particular: by the form of appearance (available resources, unused or partially used reserves, explicit and implicit opportunities); by the time feature (factual - in terms of the past, technically possible - in terms of the present, perspective - in terms of the future); by availability (available and unavailable); by degree of appearance (explicit and implicit); by the degree of formation of explicit potential (formed, partially formed, unformed); by the degree of use of available potential (used and partially used); by the level of concentration (at the national level, at the level of the region/city, at the level of the territorialbranch cluster, at the entity level); by the type of appearance in relation to the studied territory (internal and external). However, a number of questions arise and require further investigation. What should be the system for description the structural elements of circularity potential through the proposed categories? What are the new metrics to measure the progress towards circular economy based on identification and monitoring all the possible forms of the circularity potential - opportunities, reserves, available resources, rather than the available resources only? What is the role of society (producers, consumers, public bodies, educational institutions and policy makers) in enhancing $\mathrm{CE}$ and its potential?

We believe these questions deserve further investigation and we intend to follow up with the research in this area, which will hopefully enable us to answer these questions. 


\section{Acknowledgements}

This manuscript is supported by Erasmus+ Programme of the European Union (620966-EPP-12020), Ministry of Education and Science of Ukraine (0120U100884), Student Grant Competition in VŠB - Technical University of Ostrava (SP2021/18), and Ministry of Education, Science, Research and Sport of the Slovak Republic (KEGA 011PU-4/2019, VEGA 1/0508/21).

\section{References}

1. ALLWOOD J.M., CULLEN J.M., CARRUTH M.A., 2012, Sustainable materials: With both eyes open, UIT Cambridge Ltd, Cambridge.

2. BLOMSMA F., BRENNAN G., 2017, The Emergence of Circular Economy A New Framing Around Prolonging Resource Productivity, in: Journal of Industrial Ecology, 21(3), p. 603-614.

3. BOCKEN N. M. P., OLIVETTI E. A., CULLEN J. M., POTTING J., LIFSET R., 2017, Taking the Circularity to the Next Level, in: Journal of Industrial Ecology, 21(3), p. 476-482.

4. BOCKEN N. M. P., PAUW I., BAKKER C., GRINTEN B., 2016, Product design and business model strategies for a circular economy, in: Journal of Industrial and Production Engineering, 33, p. 308-320.

5. BOCKEN N. M. P., SHORT S. W., RANA P., EVANS S., 2014, A literature and practice review to develop sustainable business model archetypes, in: Journal of Cleaner Production, 65, p. 42-56.

6. BRAUNGART M., MCDONOUGH W., BOLLINGER A., 2007, Cradle-to-cradle design: creating healthy emissions - a strategy for eco-effective product and system design, in: Journal of Cleaner Production, 15(13-14), p. 1337-1348.

7. BRIDGENS B., POWELL M., FARMER G., WALSH C., REED E., ROYAPOOR M., GOSLING P., HALL J., 2017, Framework for Implementing the Principles of the Circular Economy in Organizations-Guide, The British Standards Institution, London.

8. CIRCULAR ACADEMY, 2017, Circular Economy: Some Definitions, http://www.circular.academy/circular-economy-some-definitions/ (10.11.2019).

9. COX J., GRITH S., GIORGI, S., KING G., 2013, Consumer understanding of product lifetimes, in: Resources, Conservation and Recycling, 79, p. 21-29.

10. DEN HOLLANDER M.C., BAKKER C. A., HULTINK E. J., 2017, Product Design in a Circular Economy: Development of a Typology of Key Concepts and Terms, in: Journal of Industrial Ecology, 21(3), p. 517-525.

11. Decision No. 1386/2013/EU of the European Parliament and of the Council of 20 November 2013 on a General Union Environment Action Programme to 2020 'Living well, within the limits of our planet', http://eur-lex.europa.eu/legal-content/EN/TXT/PDF/?uri=CELEX:32013D1386\&fro $\mathrm{m}=\mathrm{EN}(10.11 .2019)$.

12. DOMENECH T., BLEISCHWITZ R., DORANOVA A., PANAYOTOPOULOS D., ROMAN R., 2019, Mapping Industrial Symbiosis Development in Europe typologies of networks, characteristics, performance and contribution to the Circular Economy, in:
Resources, Conservation and Recycling, 141, p. 7698.

13. ELIA V., GNONI M. G., TORNESE F., 2016, Measuring circular economy strategies through index methods: A critical analysis, in: Journal of Cleaner Production, 142(4), p. 2741-2751.

14. ELLEN MACARTHUR FOUNDATION AND GRANTA, 2015, Circularity indicators. An approach to measuring circularity. Methodology, Ellen MacArthur Foundation, Medina.

15. ELLEN MACARTHUR FOUNDATION, 2013a, Towards the circular economy. Economic and business rationale for an accelerated transition, Ellen MacArthur Foundation, Medina.

16. ELLEN MACARTHUR FOUNDATION, 2013b, Towards the circular economy. Opportunities for the consumers goods sector, Ellen MacArthur Foundation, Medina.

17. ELLEN MACARTHUR FOUNDATION, 2014, Towards the circular economy. Accelerating the scaleup across supply chains, Ellen MacArthur Foundation, Medina.

18. EUROPEAN COMMISSION, 2015, Closing the loop - An EU action plan for the Circular Economy. Communication from the Commission to the European Parliament, the Council, the European Economic and Social Committee and the Committee of the Regions, http://eur-lex.europa.eu/legal-content/ EN/TXT/?uri=CELEX:52015DC0614 (15.10.2019).

19. EUROPEAN COMMISSION, 2018, A European Strategy for Plastics in a Circular Economy, https://eur-lex.europa.eu/legal-content/EN/TXT/?qid $=1516265440535 \&$ uri $=$ COM:2018:28:FIN (10.11.2019).

20. FRANKLIN-JOHNSON E., FIGGE F., CANNING L., 2016, Resource duration as a managerial indicator for Circular Economy performance, in: Journal of Cleaner Production, 133, p. 589-598.

21. GEISSDOERFER M., SAVAGET P., BOCKEN N., HULTINK E., 2017, The Circular Economy - A new sustainability paradigm?, in: Journal of Cleaner Production, 143, p. 757-768.

22. GLADYSHEV N. G., 2013, Scientific basics of recycling in techno-natural waste management clusters, Samara University, Samara.

23. GUBANOVA E. R., 2009, The mechanism of economic and environmental incentives for the use of secondary resources, OSEU, Odessa.

24. JAWAHIR I. S., BRADLEY R., 2016, Technological Elements of Circular Economy and the Principles of 6R-Based Closed-loop Material Flow in Sustainable Manufacturing, in: Procedia CIRP, 40, p. 103-108.

25. KAUTISH P., PAUL J., SHARMA R., 2019, The moderating influence of environmental consciousness and recycling intentions on green purchase behavior, in: Journal of Cleaner Production, 228, p. 1425-1436.

26. KOMAR I., 1975, Rational use of natural resources and resource cycles, Nauka Publishing House, Moscow.

27. KRONENBERG J., WINKLER R., 2009, Wasted waste: An evolutionary perspective on industrial byproducts, in: Ecological Economics, 68(12), p. 30263033.

28. MONT O., PLEPYS A., WHALEN K., NUBHOLZ J. L. K., 2017, Business model innovation for a Circular Economy: Drivers and barriers for the Swedish 
industry - the voice of REES companies, Mistra REES, Linkoping.

29. MONT O., HEISKANEN E-K., 2015, Breaking the stalemate of sustainable consumption with industrial ecology and a circular economy, in: Handbook of Research on Sustainable Consumption, Reisch L. and Thøgersen J., Edward Edgar, Cheltenham, p. 3349.

30. MURRAY A., SKENE K. HAYNES K., 2015, The Circular Economy: An Interdisciplinary Exploration of the Concept and Application in a Global Context, in: Journal of Business Ethics, 140(3), p. 369-380.

31. NETO J. Q. F., BLOEMHOF J., CORBETT C., 2016, Market prices of remanufactured, used and new items: Evidence from eBay, in: International Journal of Production Economics, 171, p. 371-380.

32. PARK H. J., LIN L. M., 2018, Exploring attitude-behavior gap in sustainable consumption: comparison of recycled and upcycled fashion products, in: Journal of Business Research, (in press).

33. PARK J. Y., CHERTOW M. R., 2014, Establishing and testing the 'reuse potential' indicator for managing wastes as resources, in: Journal of Environmental Management, 137, p. 45-53.

34. PAULIUK S., 2018, Critical appraisal of the circular economy standard BS 8001:2017 and a dashboard of quantitative system indicators for its implementation in organizations, in: Resources, Conservation and Recycling, 129, p. 81-92.

35. PETRUSHENKO M., SHEVCHENKO H., 2013, Management of ecological-economical conflicts within the framework of the theory of optimal mechanisms for resource distribution, in: Actual Problems of Economics, 141(3), p. 186-192.

36. PIERONI M., MCALOONE T., PIGOSSO D., 2019, Business model innovation for circular economy and sustainability: A review of approaches, in: Journal of Cleaner Production, 215, p. 98-216.

37. PISCICELLI L., LUDDEN G. D. S., COOPER T., 2018, What makes a sustainable business model successful? An empirical comparison of two peer-topeer goods-sharing platforms, in: Journal of Cleaner Production, 172, p. 4580-4591.
38. POTTING J., KROEZE C., 2010, Cradle to cradle: Old wine or new spirits?, in: Integrated Environmental Assessment and Management, 6(2), p. 315-317.

39. PROKOPENKO O.V., KYSLY V.M., SHEVCHENKO H.M., 2014, Peculiarities of the natural resources economic estimation under the transformational conditions, in: Economic Annals-XXI, 78(1), p. 40-43.

40. RASHID A., ASIF F.M.A., KRAJNIK P., NICOLESCU C.M., 2013, Resource Conservative Manufacturing: an essential change in business and technology paradigm for sustainable manufacturing, in: Journal of Cleaner Production, 57, p. 166-177.

41. SHEVCHENKO T., KRONENBERG J., 2017, Management of material cyclicity potential: example of electrical and electronic products, in: Research in Design Series, 9, p. 377-381.

42. SHEVCHENKO T., KRONENBERG J., 2020, Management of material and product circularity potential as an approach to operationalise circular economy, in: Progress in Industrial Ecology An International Journal, 14(1), p. 30-57.

43. SKENE K. R., 2017, Circles, spirals, pyramids and cubes: why the circular economy cannot work, Sustainability Science, 13(2), p. 479-492.

44. STAHEL W., 2010, The Performance Economy, Palgrave-MacMillan, London.

45. VELIS C. A, BRUNNER P. H., 2013, Recycling and resource efficiency: it is time for a change from quantity to quality, Waste Management and Research, 31(6), p. 539-540.

46. WEELDEN E., MUGGE R., BAKKER C., 2016, Paving the way towards circular consumption: exploring consumer acceptance of refurbished mobile phones in the Dutch market, in: Journal of Cleaner Production, 113, p. 743-754.

47. WEBSTE K., 2015, The Circular Economy: A Wealth of Flows, Ellen MacArthur Foundation, Isle of Wight.

48. ZENG X., LI J., SINGH N., 2014, Recycling of Spent Lithium-Ion Battery: A Critical Review, in: Critical Reviews in Environmental Science and Technology, 44(10), p. 1129-1165. 
